\title{
Communication as a Dialectical Engagement with Becoming and the Last Lesson of Don Miguel de Unamuno
}

\author{
Robert Wade Kenny \\ Mount Saint Vincent University, Halifax, Canada \\ Email: doctorwadekenny@hotmail.com
}

How to cite this paper: Kenny, R. W. (2019). Communication as a Dialectical Engagement with Becoming and the Last Lesson of Don Miguel de Unamuno. Advances in Literary Study, 7, 123-154. https://doi.org/10.4236/als.2019.74009

Received: July 1, 2019

Accepted: September 2, 2019

Published: September 5, 2019

Copyright (อ 2019 by author(s) and Scientific Research Publishing Inc. This work is licensed under the Creative Commons Attribution International License (CC BY 4.0).

http://creativecommons.org/licenses/by/4.0/ (c) (i) Open Access

\begin{abstract}
The present essay includes the only extant translation of a famous address given by Don Miguel de Unamuno y Jugo, at the University of Salamanca's annual, course-launching ritual. Given that the event's festivities would include his formal resignation from the school's rectorship on that day, followed by his honorary appointment as Lifetime Rector, Unamuno composed his speech to sum up his soul's literary journey through this world. In it, the scholar and poet effectively renders his chosen life as a rhetorical vocationconsequently, he makes claims such as "man is the animal that speaks," (a claim that resonates with Kenneth Burke) and "the spoken word is action" (a claim which is at the heart of a 100-year tradition in speech act theory). This being so, scholars of communication might be stimulated by his ideas and influenced by his relevance to rhetoric and communication. A prefatory essay, "Communication as a Dialectical Engagement with Becoming" is provided by the translator along with a copy-corrected version of the open-source Spanish original of the Unamuno translation in an Appendix.
\end{abstract}

\section{Keywords}

Unamuno, La Palabra, Interior Language, Monolects, Heteroglossia, Yo, Vital Scepticism, Rhetoric of Philosophy

\section{Introduction}

The following translation of an address given in 1934 by Don Miguel de Unamuno $\mathrm{Y}$ Jugo is presented to direct an English-speaking audience to a great master of Spanish letters. On the world stage, Unamuno is best known for The Tragic Sense of Life, which still stands as one of the monumental European es- 
says of the twentieth century. He was a novelist, poet, academic, political activist, and intellectual. He read English, French, Italian, Latin, Greek, Norwegian, Danish, German, Portuguese, Basque, and Catalan. His knowledge of philosophy and literature was thorough and exemplary; he had, for example, translated, into Spanish, Hegel's Logic, at the age of eighteen.

The speech presented here is heavily referenced in one chapter of The Rhetoric of Existence by Allen Lacy (1967), and thus serves as the proper and thorough source from which English speaking scholars might consider Lacy's claims ${ }^{1}$. Also and more generally, however, the complete translation provides all other readers an opportunity to consider the thought Unamuno's essay organizes-it is a work that stands in his opus where the "Definition of Man" essay stands in Kenneth Burke (1966). To be blunt, no one has established Unamuno's rightful position in speech studies, neither within the theoretical literature, nor the historical. This translation is one of several forthcoming contributions made by this author to correct the oversight; and should rhetorical studies, appropriately, turn some attention to Unamuno, this translation will play a foundational role in anything that is discussed.

\section{Prefatory Essay: "Communication as a Dialectical Engagement with Becoming"}

\subsection{The Social Construction of Language and the Crisis of Individuation}

Unamuno believed that becoming an individual was the most challenging and important task of human existence; a belief that is inextricably entwined with his understanding of spoken language. If he had to solve Christ's riddle about the camel passing through the eye of a needle in the Oedipus/sphinx modality, he would surely say, "It means you have to strip off the burden of every wrongheaded idea that is given to you in your life; that you must keep only those that you have with determination refined and embraced as your own, so that you become the concentrated essence of yourself, which is thought, distilled from the speaking you have heard across your lifetime, existing now as nothing other than your perfect soul, which you have transformed, during your existence as the man of flesh and bone, into a filament of purified ideas that can be passed through a needle and used to stitch the garment of the one, eternal God."

According to Unamuno "thought is interior language" (Unamuno, 1984: p. 29) made possible by virtue of our prior experience of an outward language that is found within both the everyday chatter of the ambient idiom and the formal expressiveness of a national tongue (Unamuno, 1984: p. 29). Of course, this claim also obliges Unamuno to assert that "thought and logic are social." (Unamuno, 1984: p. 101). We would have then, assuming this was the end of the matter, what later authors (e.g., Mannheim, 1952) have since named the "soci-

${ }^{1}$ Hughes (1978), for example, tries to develop a platform for educational studies by reading Lacy's interpretation without accessing the original speech.

${ }^{2}$ The passage is an imaginary one which is based on Unamuno's philosophy of language and is provided as an explanatory mechanism to make the philosophical concept under discussion more clear. 
ology of knowledge", a theory that would leave ideas no more than the pragma that arise from within the socio-phenomenological experience of human agents. Transcendence and ideas of truth would collapse under this admission; and we would be compelled to accept that neither our languages, nor the thought that arises within us in the forms given to us by languages, live originally in the mind of God. Human language and human thought would come, then, to be regarded as regional experiences, separated from each other, as people are, across the oceans, and rivers, and mountains that serve as barriers, not only between their bodies but their spiritual nature as well. Therefore, even a great philosopher, being first and ultimately a social agent, would be capable of no more than "unearthing and developing the secular metaphors of his own language." (Ferrater, 1962: p. 88).

The notion that language and the thoughts it gives are social then, that they migrate from one person to another, from one village to another, from one province to another, and from one nation to another consequently suggests that language is both imperfect and fundamentally in conflict with any other person who engages with it, as my sentence here may not be consonant with the thoughts the present reader already experiences. It is a consideration that problematizes notions such as 1) that one person can ever understand another, 2) that one person can ever agree with another, 3) that one person can ever have one's own thought, and 4) that societies can ever come to accord.

\subsection{Dialectic as the Pathway to Both Individuation and Truth: The Emergence of the Yo}

The issue of a multiplicity of monolects is akin to Bakhtin's notion of heteroglossia, though its resolution is actually a strategy derived from the dialectical thinking of Unamuno's beloved Hegel ${ }^{3}$. That resolution begins with the postulate that, whereas we all speak our own and several ways, we correspondingly intrude upon the mental life of our social cohort via our distinct ways of speaking, imposing a cacophony of language-styles, references, and values not necessarily held by individual and collective listeners. For the novelist, this imposes the compositional challenge of holding apart, within the mind, these distinct voices, so that they can then be rendered as characters, including narrators, within ${ }^{3}$ To a great extent Unamuno found his theory of self-emergence from considerations of Hegel, but his innovative assembly of that idea can be seen as one that is derived from his specialty in philology in which it is demonstrated that "dialectical diversions, like all language changes, are directly due to innovations." (Pei, 1965: p. 50). Such regional language "innovations" challenge the social force that normalizes speech patterns, creating original ways of speaking that may move across vast regions of expression until its popular usage pressures “the people who direct the nation's linguistic policies...to determine whether the innovation shall be considered as forming part of the standard language." (Pei, 1965: p. 50). Even where that is not the outcome, however, the innovation may preserve its life in the regions that venture to use it, under the heading of dialect, among which there are so many associated with the Spanish language. In the basic concept of dialect, that is to say, we see the idea that those who are given a manner of speaking tend at the same time to shape it to their purposes, against whatever authority the original gift of a language imposes. Unamuno effectively saw within this normative philological observation the potential to extend the idea, conceiving the notion that the ideas implicit in a language could be accepted by a people but also those recipients could innovate upon those "ideas" to their own purposes. In this way, the theory of language as social order is subject to a pressure in the direction of re-ordering from below. 
a text (i.e., heteroglossia). For a philosopher, on the other hand, or even a novelist who is not in the middle of writing fiction (or any other sensible person, for that matter), these different voices, now internalized, gather the individual's mental effort in a direction that seeks order, they impel the mind to engage in the natural process of rendering from this "noise" a sensible symphony of words and ideas, regardless that they came originally from others, just as one composes one's own song by setting aside any background noise or irrelevant melodies created by others. Given Unamuno was so deeply taken with Hegel, we might put it thus: to the extent any person encounters various ways of speaking, that person will engage those now internal and discordant voices as a sort of internal argument or contestation; and the strain of these differences will perpetuate such cycles of idea-contestation, akin to the notion specific to the Hegelian dialectic (thesis/antithesis), bringing about a compulsion to resolve (synthesis), which ultimately positions the individual as a stance taker, as in the expression this is what I stand for, or $I \mathrm{am}^{4}$. This is the essence of what Unamuno refers to when he mentions the $Y o$ in his own writing. While it is commonly no more than the term used for self-referentiality as a subject (much as we would say "I am going to the store."), the $Y o$, for Unamuno, is a philosophical achievement-a point in self-development that one reaches by accepting the challenge of making-sense of all the discordant inner-language that one faces. Thus, a teenager can watch highly romanticized television advertisements for military careers and say, "I want to be a soldier." At this point, the parent may take the young person to a facility for injured veterans, so that the adolescent may be confronted by former soldiers shaping ideas about war in their speech. To be sure, after spending an afternoon with these people, hearing their stories, the young person may still say, "I want to be a soldier." But Unamuno would not see the two statements as identical, regardless that the same words were used in both cases. His philosophical understanding of the Yo would cause him to suggest that the first of the two statements involved no genuine subject position beyond a mimetic voice parroting what had been spoken within the advertisement, as if identity were nothing more than appropriation and impersonation. On the other hand, after the visit to the veteran's hospital, the interior language (thought) the boy was given by the advertisement would surely clash with the new interior language ${ }^{4}$ The demand for consistency in social reason, however, is subverted in advance by the complex daily social environment in which an individual is expected to constantly migrate-and-occupy various moral, conventional, discursive, and behavioral modalities, where failure to do so results in the loss of role and status, as well as its corresponding relational and economic consequences (Kenny, 2010: p. 223). No doubt this is why expressions such as "I don't know who I am. Everything about me is a lie," has become a virtual mantra in some psycho-therapeutic offices. Indeed the clinical version of this as a defense mechanism has been identified by Grotstein (1977) and others as "splitting", but it is also a normative cognitive-emotive performance expectation wherever social orders are micro-assembled or fragmented, a pressure that diminishes the tendency of any interior monologue or subject to encounter another internal monological modality. The strategy is socially efficient because it facilitates the inconstancy that is compulsory in complex social networks, while at the same time it suppresses or obviates the strain of maintaining a morally constant character. Yet this dialectic between being a person and being many persons is a paradox that cannot be resolved by postmodernity. Often championed, the celebration of not-being-a-self (Doyle-McCarthy, 2017) turns bitter where constancy of idea and commitment is required. 
(thought) he gained by talking with the soldiers. If the young man listened to both voices, and struggled with those voices, and finally arrived at a resolution of what had been two internal voices, Unamuno would be satisfied that the second utterance had arisen as the consequence of a genuine resolution and commitment to a subject position. To reach that point, to be a $Y o$, is at the foundation of Unamuno's work ${ }^{5}$.

It is indeed with this understanding in mind that Unamuno formulated his own presentational methods. Recognizing that the purification of thought involved the clashing of ideas, and not the swallowing of them whole, he says:

My intent has been, is, and will continue to be, that those who read my works shall think and meditate upon fundamental problems, and has never been to hand them completed thoughts. I have always sought to agitate and, even better, to stimulate, rather than to instruct. Neither do I sell bread, nor is it bread, but yeast or ferment (Unamuno, 1945: p. 8).

The proposition is a stunning one for it makes clear that Unamuno never sought to give us his ideas as answers, but as provocations to answer for ourselves by exploring deeper answers that are particularly our own. It is, all in all, an idea worth contemplating for some time, in that we have seen the general social failure of this ambition, and the way it has expressed itself in mass culturesomething Ortega y Gasset (1929) pointed to ${ }^{6}$ even as Unamuno wrote, providing us the notion of a mass man, so comfortable within ideological cacophonies that he glorifies them as the very name of his era (i.e., post-modernity). This new humanity, which Ortega and Unamuno saw (their most determining point of agreement) was a humanity uninterested, incapable, possibly contemptuous, and even opposed to the notion of a determining or defined position in a world that

${ }^{5}$ In this sense, José Ortega y Gasset is decidedly in error when he claims that his fundamental contribution, yo soy mi y mi circumstancias (I am me and my circumstances) represents his original contribution to philosophical thinking. It appears that Unamuno was working along the same terms. ${ }^{6}$ e.g.,

My subject is this: today people constantly talk of laws and law, the state, the nation and internationalism, public opinion and public power, good policy and bad, pacifism and jingoism, my country and humanity, social justice and social injustice, collectivism and capitalism, socialization and liberalism, individual and the collective, and so on and so on. And they not only talk, in the press, at their clubs, cafés, and tavern; they also argue. And they not only argue; they also fight for the things that these words designate. And once, started fighting, they kill each other-by hundreds, by thousands, by millions. It would be ingenuous to suppose that, in what I have just said, I refer to any specific nation. It would be ingenuous, because the supposition would be equivalent to believing that these ferocious performances are confined to particular parts of our planet; when, on the contrary, they are a universal phenomenon that is progressively spreading and by which very few of European and American peoples will succeed in remaining unaffected. Doubtless the cruel conflict will be more mortal among some than among others and it may be that one or another will possess the inspired serenity necessary to reduce the havoc to a minimum. Because certainly conflict is not inevitable; but no less certainly it is very difficult to avoid. Very difficult indeed, because to avoid it will require the collaboration of many factors that differ, both qualitatively and in importance-splendid virtues, together with humble precautions.

One of these precautions-humble, I repeat but obligatory if a country is to pass unscathed through these terrible times - is somehow to contrive that a sufficient number of persons in it shall be thoroughly aware of the great degree to which these ideas (let us call them ideas) -all these ideas about which there is all this talk and fighting and arguing and slaughter-are grotesquely confused and superlatively vague (Ortega, 1956: pp. 161-162). 
celebrates (e.g. "My truth") non-integrated differences (even within the self) -a humanity that existed as a form of mental lassitude, of indiscipline, thanks to the pressure of other internalized voices arising from phenomena such as propaganda and advertising; indeed, even a humanity that could be conceived as a spontaneously emergent gathering of single-minded drones of capitalism, industry, politics, or the state, a mass, easily hypnotized, by one of those programmed, interior voices, to fall into the robotic self that its language demands. And, of course, this was the humanity that would bring Spain to a bloody precipice a few years later.

Unamuno believed that the general condition he described could be overcome by disciplined thought - that a critical listener could chisel the imperfections from the surrounding, rough-surfaced voices, through dialectical engagement with them, ultimately carving thereby his or her own Yo, finding thereby a unique and ownmost self that always stands in the midst of such discrepancies of utterances and dialects. In the same way, Unamuno believed that people could do this with each other. To Unamuno, "words... like human beings... live in a constant state of war, of tension, of conflict;" (Ferrater, 1962: p. 88) and he believed that this tension, already existing within a person and indeed within a language (Pei, 1965: p. 50), could necessitate an exercise in reason as the negotiation of already internalized conflicts ${ }^{7}$. Thus, he was committed to the relationship between language and thought, holding that the true individual was a person fluent in various languages and/or dialects; therefore already compelled to engage in a thinking that occurs as the internal debate that he refers to as vital scepticism (Unamuno, 1913: p. 131).

No single internal voice can confer that genuine thinking, however. For example, with regard to a person's cosmopolitan and rural idiom the rector says that, "Both tendencies are like two pairs of glasses modifying correct sight; one of them shortsighted, the other of them farsighted. And you see just as poorly through one pair as the other." (Unamuno, 1945: p. 60) ${ }^{8}$ Unamuno, consequently, could not regard formal speech as a stand-alone solution to either the problems associated with linguistic diversity or the problems of cultural variance. And, to be direct, he did not regard these differences as problems; rather, he championed them as conditions for the refinement of both speech and thought ${ }^{9}$. For Unamuno then, a grand style that is embellished and culturally sophisticated finds itself balanced, in his work, against a style of speaking that

\footnotetext{
${ }^{7}$ This is something akin to the universal speech act specified by Jürgen Habermas - not that they are identical, but they might have, as Unamuno would joyfully cry out about any two ideas, an interesting conversation with each other.

${ }^{8}$ How close this is to Kenneth Burke's notion of perspective by incongruity and the double vision he experienced while writing about it in Permanence and Change!

${ }^{9}$ In this sense, Unamuno's vital scepticism is cousin to Marshall McLuhan's concept of the probe, which he uses to demote the authority of his own utterances by suggesting they are invitations to wondering rather than facts to be remembered-another version of the idea that language can be used to introduce genuine thinking rather than shutting it down. On this concept of the probe, so similar to Unamuno's vital scepticism, McLuhan says, "I'm not interested in my statements. I don't agree with them. I merely use them as probes." (McLuhan in Finkelstein, 1968: p. 14).
} 
is unsophisticated, yet cultured and deeply rooted in the individual's spirit. Formal grammar, for example, means less to him than the vital grammar that people take up through the experience of living; and that is why he says "Grammar does not teach speaking or proper writing." (Unamuno, 1958: p. $713)^{10}$ Rather, proper speaking can only be for Unamuno the result of being amongst others in one's community, where he places the home of language, a home that might be described with, but not built upon, formal grammatical principles - a notion that resonates with Gerry Philipsen's (1997) more-recent speech code theory.

\subsection{Unamuno's Other Ideas Relevant to the Following Translation}

1). Unamuno precedes many of our disciplinary markers in his own work. Consider, for example, the words originally presented in his much earlier inaugural address of 1900, over a century ago, and thirty-four years before the day he repeats them in this translated lecture:

Spoken language, I say. You might superficially grasp how a language can live, but you will never grasp this idea with active and creative comprehension unless you open your ears to the sounds of your own region, unless you direct yourself faithfully and attentively to the idioms of the populace-to what they say and to their sayings, to all that so-called barbarism, that has been customarily kept outside intellectual consideration, thereby making the tongue a product of a literary pact subject to academic prescription (Unamuno, 1958: p. 496).

Of similar relevance, he says, as early as 1913:

A language, in effect, is a potential philosophy. Platonism is the Greek language which speaks through Plato, developing in him its ancient metaphors. Scholasticism is the philosophy of the dead Latin of the Middle Ages struggling against the various vernacular languages. French discourses through Descartes; German through Kant and Hegel; English through Hume and John Stuart Mill. The logical point of departure for all philosophical speculation is not the " $P$ ", nor is it representation (Vorstellung), that is, the world as it immediately appears to the senses, but rather is it a mediate or historical representation, humanly elaborated and given us principally in the language through which we know the world (Unamuno, 1984: p. 310).

With such commitments, commitments that effectively postulate a rhetoric of philosophy, and consequently a rhetoric of science as well, Unamuno inevitably becomes a provocative thinker for scholars of rhetoric.

2) Because Unamuno extends his communication-thinking model into a communication-thinking-acting model, he is also able to discuss the ultimate effects of ways of speaking upon the motivations, political (in particular) or otherwise, for a people. That is why he announces in this essay "that there is no separation of the spoken word from the deed." Unamuno believes that clearer language leads to clearer thoughts, hence clearer motives - in other words he effectively pro-

${ }^{10}$ The idea resonates with Richards \& Ogden (2007) notion of the proper meaning superstition, as well as their famous mantra: words don't mean, people do. 
vides a platform for a linguistically determined ethical theory. He also recognizes that unclear language leads to unclear thought, which leads to unclear motivation; hence that language becomes increasingly pathological as its terms become vaguer $^{11}$. For Unamuno then, any pathology of language ultimately produces pathological thinking, acting, and community, and, in this sense, language and e-motion are also fundamentally intertwined. Unamuno can therefore say that "consciousness is a disease," (Unamuno, 1984: p. 22) but he believes that a critical relationship with speech, in its various manifestations, relieves the symptoms:

Reason... is a social product. It owes its origin, perhaps, to language. We think articulately, that is, reflectively, thanks to articulate language, and this language arose from the need to communicate our thoughts to our neighbors. To think is to talk with oneself, and each of us talks to himself because we have had to talk with another." (Unamuno, 1984: p. 29).

Indeed, Unamuno believes that, "The world, what we call the world, the 'objective' world, is a tradition... given... from a complex of ideas, images, notions, perceptions and so on, embodied in the language and transmitted to us by our forebears." (Unamuno, 1984: p. 161). To make such a statement (originally in 1913) is to be on the cutting edge of intellectual history-more than a decade in advance of Heidegger's characterization of world, in Being and Time.

\subsection{General Considerations When Reading}

1) The following speech, which has become known as Unamuno's Last Lesson was, indeed, his last in a cumulative intellectual sense. He had about two years earlier returned triumphantly from exile, once more a cause célèbre, following the ousting of Primo de Rivera. Soon, however, he would stand before a podium and oppose Franco's cronies; and this would have its own consequences-he simply could not lie down and play dead (Portillo, 1984). On this occasion, however, he is not so political and caustic as he had been, and would be about two years later, on the day that Rudd refers to as "his day of destiny," (Rudd, 1976: p. 294) when he spoke out against one of Franco's generals from a stage where Franco's wife was sitting. By contrast to that day of such momentous significance in Spain (Kenny, 2019), Unamuno treats intellectual matters first, here on the day of this presented-speech-language, in particular. He attempts to sum up critical aspects of his thinking and to fashion a thread which weaves through the fabric of his intellectual life; and, in particular, to guide the audience along the pathway described here, a path that refines the thought of the individual $Y o$ as well as the community, the province, and the nation, to say nothing of the human race. Hence he will say to his audience in this speech:

Each of us must form, and reform, and transform his proper dialect, individu-

\footnotetext{
${ }^{11}$ Yet this is a notion that is broader than the Socratic psycagoga/elenchus, the Socratic method that engages with the distinctly confounded idea by pointing out its inconsistent relationships with other ideas. Unamuno is less focused on the muddled thought than the muddled self or a muddled people. Moreover, the strategy he describes is part of what he regards as a normal mental life, where Socrates had to introduce these strategies as a "midwife" to people ignorant-of or comfortable-with the cognitive dissonance in their mental lives.
} 
al and regional, his proper idiom-an idiom which I want to say is proper to him-inside of the common idiom and enriching it by enriching himself within it (Unamuno, 1958c: p. 1082).

By reason of such grand ambitions, Unamuno makes sweeping claims such as "Man is the animal that speaks," and "the spoken word is action." Throughout his talk, he directs his audience to attend to spoken language, and to a written language that bears witness to the power of the spoken. For him, this is both a political and a spiritual commitment. As a philologist, he was well-aware that Antonio de Nebrija had published Arte de la lengua castellana in 1492, the same year Isabella and Ferdinand secured the Spanish nation by driving the Moors out of their last stronghold in Granada. The serendipitous connection between these two events suggested to him the fundamental relationship between common language and common identity, as it did for all of Spain — which, indeed, was the first European nation to establish a national language, right around that time. Yet Spain has always remained, paradoxically, a region of diverse ways of speaking and diverse ways of living; and it has persisted in this fashion for centuries. Unamuno was grateful for this sort of contestation and difference because he maintained that the rootedness of Spanish character and dialect in regionalism appropriately counterbalanced the influence of national language upon the individual mind, so that one ends up neither a provincialist nor a nationalist.

2) Like so many twentieth century authors, Unamuno writes with a distinct and abrupt flair that poses a challenge even for readers who take him up in his language of origin; and this makes translating a unique responsibility, for it forces the translator into a tension between the aesthetic and conceptual significance of the piece - a trap that must necessarily be set by any author who believes that the role of distinct languages is to make thought clash with itself ${ }^{12}$. Wherever he finds an opportunity, Unamuno plays with the words that he uses in terms of associations - this is because he sees all his speech acts as poetic events - as chances to introduce paradoxes that lead to new epiphanies, new ways of seeing. For example, when he describes translating one's ideas so that they can be understood by another, he plays with the Italian expression traduttore/tradittore (i.e., translator/traitor). Similarly, in this essay he will say, "I have tilled my soul," suggesting the relationship between the English words soul/soil; and, thereby, poetically suggesting the disciplined labor by which the philosopher cultivates thought. And can we not see how predictable that sort of serious joking would be to an author with the literary commitments described above? At the same time, his unique style edges the reader toward an unusual readerly approach, counseling below the level of conscious awareness that his texts should never be read as a series of interconnected paragraphs leading to a single conclusion. Instead, Unamuno would like us to approach him in the manner we read Pound's Cantos, for example: each passage a presentation of poetic events that balances its responsibility to lead to the paragraph that follows against its other duty to lead away from the page and into the higher order of reflective medita-

${ }^{12}$ This is the standard explanation for the language particular to Being and Time, as well. 
tion, contestation, and renewal within the mind that, Unamuno believes, properly advances the destiny of both language itself and the soul's journey. Effectively, then Unamuno is using his own version of McLuhan's probes, what amounts to a rhetorical device. And whereas our author pays much more attention to provoking thought than he does to resolving it safely and precipitously, the reader is advised to treat individual passages reflectively and expansively, with less attention than usual on how this author "clearly" gathers and synchronizes ideas specific to the essay, and more attention to the ways each separate idea challenges one's thought on its own. Unamuno is not trying to create clear ideas; he is trying to create challenging ones. It is the difference between the scattered utterances of Emil Cioran and a cookbook recipe. At the same time, there are occasions when Unamuno might be so vague as to leave a reader unable to see either the relevance of the utterance to its immediate context or its association with his work in general. In the worst of these cases, I have chosen to perform translation as clarification rather than translation as specification. In this way, by adding a few words, I have been able to draw out the meaning of both what precedes and follows that axial point. Anyone who knows both languages as well as Unamuno will understand why I have done this in the several places where it occurs.

3) Much good thinking went into Unamuno's speech, but that original thinking was presented in an original form, as thinking has often been for other twentieth century thinkers, like Martin Heidegger and Kenneth Burke. One naturally wishes for the ideas to be drawn together-linked into a grand system of names and addresses for everything. We forget how few great thinkers of communication actually offered any such thing-neither Burke nor Bateson, for example. Rather, it is we, ourselves, who often pour over the seminal texts, to extract the implications of scattered and scattering genius. I think the best of us can do this with what Unamuno offers. Indeed, there could be a very nice essay written on disorder and synthesis by reflecting on this activity in one or several cases.

4) Further to Unamuno's proclivity for paradox, let us return for a moment to the soil/soul relation that Unamuno uses in his first sentences, alongside a corresponding claim that he repeats himself to renew himself (like a farmer who replants in every season). The repetition/renewal (i.e., recursivity) notion is one that he will also bring up several times through the speech to remind his listeners that any soul failing to plant the seeds of spoken thought, that they may grow towards the heavens, becomes entombed within the soil-that, under the circumstance of an uncultivated life, the body goes to its grave as flesh and bone and, with it, the man-that-was decays into eternal silence. Correlatively, there will be some suggestion that spoken words are (as Socrates suggests in Phaedrus) seeds that can be cultivated across time and within one's community in such a way that they, as flowers of that person's life, bloom eternally. Soil and soul references are, then, something to which a reader should attend, because both the metaphor and the concept that the metaphor represents will be found in other writings by our prolific Spanish author.

5) Some part of what Unamuno writes and feels does not exist for an English 
speaking audience, another part has virtually antithetical status in our culture. Unamuno would only cheer the comment and call out, "A chance for you to grow!" Nevertheless, we would say, for example, that Unamuno has a problem with excessive machismo; yet his machismo, in its time and place, was a condition for generating eloquence in the text. Such articulations have a different effect in contemporary English, academic circles than they had in Spanish circles 90 years ago; yet, to obliterate them in translation would repair Unamuno and his culture in a manner that would obliterate its history. For the most part, I have let them stand for that reason, and also because I have no interest in creating a non-problematic intellectual character for an author whose ambition was disruption. Hopefully, readers can grow through this in their reading, by learning to treat a single text as both imminent and historical, by learning to read both along and across it; and finding no failure in that. Similarly, there is a generally Spanish flavor to the text, in terms of sentence structures, interjections, references, attitudes and the like. I could not have adjusted for many of these without recasting the entire document and pressing my own hand into the essay, an impropriety when translating for both conceptual-theoretical and historical purposes. Instead, I have chosen to keep the text as close as possible to a literal translation; and this may be the best choice, for the overlay of Unamuno's thinking and speaking, as a Basque and a Spaniard, flavors the document as age flavors wine and does not need me to turn it into vinegar. One gets, at the very least, a feeling for Unamuno's claim that a language is a way of living and experiencing, if only because the idiosyncratically Spanish aspects of the translated text, originally placed there to accentuate the unique character of the Spanish language and therefore the Spanish mind, remain so difficult for a non-Spanish audience to internalize.

6) It is clear that Unamuno's speech testifies not only to the significance of communication as a theoretical discipline, but also to the role played by speaking as mediator between the individual, the region, and the state. In his text then, we may see a call to seek in our own language and its variants what Unamuno urged his students seek - a generalized conviviality with others, and an ability to see, alongside them, more of human truth by engaging in speech dialectics with those who are different. When he speaks of an "intimate civil war," for example, Unamuno means that each Spaniard should try to absorb as many ways of Spanish speaking (and consequently thinking) as possible. Then, any conflict that occurred between Spanish peoples would occur instead within every individual, as a wrestling with ideas (as he will have Jacob wrestle with the angel within this very speech - what amounts to a spiritual struggle to discover identity, made clear by the repeated expression, give me your name (i.e., your spoken wordwhat ideas you stand for), that I may be blessed). Indeed, if his audience had been able to hear him on that day and in that way, Spain might have, in Unamuno's time, gone forward without bloodshed. Largely and unfortunately, this point, one of the most important contributions that Unamuno made to his people, was overlooked in its time, as the country moved rapidly toward self-destruction. It would do people well in our era of intractable contestation to con- 
sider it. In Spain, however, nothing good came of it -and Unamuno himself noted the unlistening. Nevertheless, combative as he seemed, Unamuno would be no champion of the brutality to come. In his genuinely last occasion for speaking (the occasion that finished him politically and otherwise) he stood up against the Nationalists, denouncing their thirst for blood and death—saying, for example, "You will win, because you possess more than enough brute force, but you will not convince. Because to convince means to persuade. And in order to persuade you would need what you lack-reason and right in the struggle." (Unamuno, 1936, in Portillo, 1984: p. 269).

7) Almost immediately within his lecture, Unamuno will mention his self-exile from Spain for the years during which the country was governed by the dictator Primo de Rivera; and he will say that his self-exile (a more complex historical event) was taken in order to defend speech, translated as la palabra. It should be understood that Unamuno's use of la palabra here and always is much closer to the Greek and even Biblical use of the Greek word logos, which particularly respects the power of language to call things into existence. Of course, for Unamuno, the thing that is principally called into existence is the Yo. But, more generally, this notion that speech calls forth is one with which we are familiar. It appears in utterances such as abracadabra, but also more seriously in God's manifestation of the existent world through His logos, His Divine Breath, which calls all things into being on the first pages of Genesis. Unamuno recognizes this power in humanity (although a lesser form), breathed into the Adam by God, in terms of its power to call all ideas into presence through speech. Thus when Unamuno defends the freedom of la palabra, he is at the same time defending not only the freedom to speak but also the spiritual and ultimately social life of the nation, given that the territory of a nation is its soil, and the soul of a nation is its language. This is a critical element in Unamuno, for one reason because it is at the core of his philosophy; but also because he will later be condemned again for his exercise of la palabra-this time by Franco in what will become a central historical event and cultural mythology of the Spanish Civil War. Of relevance to this idea is Unamuno's claim that the de Rivera exile was his very teaching in absentia. The great lesson of that absence is the price of la palabra - that the authentic speech of an individual or a community is an expression of courage because one commonly anticipates a heavy price for releasing one's genuine soul into the thoughts of others (who often don't want to hear those thoughts), through authentic utterances, as he had paid when driven out of Spain by de Rivera and would soon pay again at the hand of Generalissimo Franco. The issue here, then, is rhetorical courage, which Unamuno barely mentions in this text (i.e., when he talks about giving one's life for the spoken word), but which will be discussed in detail by this author in a soon to be published essay. Its central principle is that great speech is properly derived from the qualities particular to a person (in this case the virtue known as courage), not a mere talent for well-phrased utterances.

8) As the prefacing-essay has shown, Unamuno championed the ultimate res- 
olution of tensions between people as tensions that are resolved by thinking about the ideas given in language, and he says in the speech translated here that, "More has been gained by the Spanish word that flowed from the pen of Cervantes in his Quixote, son of the spoken word, than was gained by Juan of Austria with his sword in the battle of LePanto." This does not mean that, in times of crisis, such as the one within which we now find ourselves, things can be resolved if we just sit down and talk. What it suggests, however, is that the sword is not a sufficient condition to resolve the conflicts between peoples who are radically different, and that a deep internalization of the contrasting linguistic heritages from which they arise will bring about the only proper resolution. Yet, I think he makes clear that this possibility will only be consequent to a moral commitment-that Spaniards must present themselves to others with an overall ability to experience difference, as he mentions in this essay, to challenge the other saying "give me your name (i.e., your word)!" —an invitation to dialectic, at the outset, rather than a refusal of it. And then, a receiving of that name, when it is given - that is, an internalization of the other's truth and a willingness to engage in the discord that this new truth brings about within the self, for the sake of refining the self. It is, of course, a strategy directly opposed to the more common response: How dare you say, which has surrounded us through history and now appears with striking regularity in our own era of raving unspeakability, in which people are offended by the words, and therefore thoughts, and therefore the very souls of others in their community. It is what happened in Unamuno's time. What good came of it? Countless dead, impoverished, homeless. The consequences have plagued Spain for nearly a century, the bitterness even now.

Unamuno, of course, offers another path. He suggests that a willingness to receive the spoken thoughts of others, followed by a willingness to struggle internally, as Jacob did, with such thoughts, is the ultimate condition for the development of human relations, living cultural history, and a soul that can eventually evolve the language of God. Again, we see in this the relevance of what Unamuno has to say to our own time.

9) Unamuno will focus on repetition at the opening of this essay, for he believes that vital ideas are renewed when they are repeated. This renewal is not simply a washing away of time, rather it is the giving of newness and new time to ideas by speaking them again, much in the way a poem gives us something new with every reading, because we bring something new to it." Repetition thus involves a rebirthing of ideas that is rooted in Unamuno's philological commitments, as well as his soil-renewal metaphors. Clearly, for example, our Spanish author felt that the ancient Greeks come to us renewed with each time we visit them much as the translator here attempts to renew Unamuno's thoughts of almost a century ago for the sake of the current, cultural stage. Unamuno clearly suggests that he models his own speech on such a re-beginning. By consequence, the subtleties of his first few lines are grounded in that commitment, including his characterization of thinking as farming, an annual cycle that renews crops each year, yet one discussed in such a way that the "cultured" intellectual does not lose sight of his 
rootedness in the "agri-cultured" world.

10) There are many references to Christianity in this document, so the fact that Unamuno was charged with heresy by the bishop of Spain fifteen years after his death, his works considered blasphemous, bears mentioning. When reading, one should bear note that Unamuno was trying to think Being through Christianity in an original way, and he was willing to radicalize the concept of the Christian, even treat it as an analogy, in order to mediate the existential dread of tragic human existence (Marias, 1966: pp. 192-211). One must read Unamuno in this spirit, or one mistakenly feels bored, of occasion, by what appear to be the words of a latter-day, excommunicated Church apostle. The idea is absurd, but that would be another essay, and certainly not necessary for anyone who has followed along thus far.

11) The translation presented here was originally accepted by Communication Quarterly, the journal of the Eastern Communication Association. A new chief editor, who was not interested in the subject, took charge during revisions, and the acceptance decision was rescinded. I am therefore grateful to Advances in Literary Study for its acceptance of this important work, as well as the fine job they have done preparing it. In addition, I extend my gratitude to University Distinguished Professor Albrecht Classen, philologist and medieval scholar at the University of Arizona, who, himself, once studied at the University of Salamanca. Professor Classen's fine review and subsequent support were a great resource in the preparation process. I thank the late Professor Xavier Monasterio from the University of Dayton and acknowledge the late Father Thomas Regis Murphy of Pittsburgh diocese for their help with subtle linguistic and theological details in the text. I also thank my friend, Álvaro Miguel Barrios, for his thoughtful assistance resolving technical errors that problematized the Spanish original. As we proceed to Unamuno's essay, there is little else I can say if I am to avoid the charge of pedantry Unamuno makes against my kind in the body of this talk. Therefore I now leave the rest to him.

\section{Translated Speech: The Last Lesson of Don Miguel de Unamuno}

DISCOURSE READ DURING THE SOLEMN INAUGURATION OF THE 19341935 ACADEMIC COURSE YEAR, IN THE UNIVERSITY OF SALAMANCA, THE 29 DAY OF SEPTEMBER, 1934 AT HIS RETIREMENT FROM OFFICE

Friends, masters, and disciples - students all:

What memories - some far off, others recent-of coming to this crossroad moment in which I inaugurate your send-off by repeating myself, always one more time, here in our university's grand ceremonial hall, where so many spoken words from other years, uttered by so many of Spain's eternal voices, still resonate around us. I come to repeat myself, I repeat, to renew myself. The core of a spiritual life is repetition, saintly fulfillment of the daily tasks, of one's destiny and one's vocation. Day by day I have tilled my soul and the souls of others, youths, from my professional office as university teacher and mentor. What I teach is, before all and over all, learning. 
I began my first course, Greek Language and Literature, the only course I taught at that time -in 1891, forty-three years ago, coming from my native mountainous Vizcaya, to the high plateaus in order to strengthen this skin and bone that had been forged by Vizcaya's native mountains. And during forty three years of teaching (I would like to count among them those during which I submitted myself to exile for defending the liberty of the word, an act which I regard as my teaching in absentia) I have been with you here, in this university, to forge the universal and eternal Spain. I, myself, read the inaugural discourse, "Exhortative Allocution," as I called it, in this very room in 1900; and soon after, in that same year, I was elevated to the first rectorship of this deeply Spanish school.

Today it might be better for me not to mention my extra-university activities, particularly those political. However I doubt that I will be able to do it: after all, does one teach only in the classroom? And in that "Exhortative Allocution," which was anything but an analytical dissertation, presented thirty-four years ago, and now that moment seems to join us as a stratum of the present, in the manner of what is truly historical -I told you, young students, or rather to your fathers, but it amounts to the same, "God grant you would come full of freshness without the imprint of dejection from fifteen or twenty previous tests, and bringing to this sacred place no greediness for note-taking, but with a thirst for truth and hunger for lifelong knowing, and with the smell of the market-place, of the country, of the village, of the great school of life spontaneous and free!" That is what I told you when I was thirty-six years old; and that is what I am repeating to you today, now seventy, as part of my own examination of myself ${ }^{13}$.

By teaching, and learning to teach, the eternally young and eternally ancient tongue and letters of Hellenic peoples (antiquity is the birthplace of our people and antiquity is equally the birthplace of one's spiritual life) I was re-tempering my rebellious spirit by disciplining it. Disciples must be disciplined. And thus the symbolic soul of Socrates, the son of a midwife, came to assist me-Socrates, who called himself a great midwife, who assisted youthful Athenians to give birth to their own spiritual enlightenment; to see the world with proper and clear consciousness, and thus to re-create what has already been re-created in it. And this by way of the spoken word, for Socrates, like Christ, the Verb ${ }^{14}$ left

\footnotetext{
${ }^{13}$ Here, Unamuno implies that the concept of examination (so prominent in the minds of students before him, who might imagine it an odious experience) is not a mere institutional challenge, but is an ongoing responsibility directed at the self, in order to take the measure of one's life.

${ }^{14}$ When Unamuno refers to Christ as, el Verbo he is playing with the relationship between words and actions. The idea is deeply connected with his notion of la palabra, so closely connected to the Greek $\log o s$ and its Biblical representation in Genesis, when God's divine breath (the breath that is turned into speech) demonstrates its magnificent power to create the universe simply by speaking it. Unamuno held that man carried some of God's divine breath, as it had been blown into him at creation, so that one man, or woman of course, could create ideas in the mind of another by speaking. It was God's divine power to create the universe itself by speech (e.g., Let there be light), and it was God's speech (the evocation and evacuation of intention from the mind of God into the air) that released Christ into the world. Yet Unamuno also believed that each new Adam, each person, is capable of becoming a Christ, understood as the physical embodiment of God, by perfecting God's spirit, which is (for Unamuno) the idea-made-manifest-in-speech; and by contributing-to and partaking-of the collected, authentic utterances of the human race in La Palabra, writ-large as the collected and purified ideas of speech as articulated or interior thought (a discourse-driven version of Hegel's notion of the Absolute).
} 
nothing written; he did not bury himself in the written ${ }^{15}$.

Sometimes I have said, to the astonishment of certain pedants, that the true Spanish people's university has been the cafe and the public place. Pedants believe they have a monopoly on thinking; they make their living from it, and they look down upon the wasting of mental energy in extended periods at casinos and cafes, in get-togethers, in accidental reunion with friends. They consider such time lost. Lost? Why? Coffee shops are filled with genuine and genius Spaniards, Socratic spirits, Spaniards through and through, whose names are not granted a legacy, but who conserve and enrich the oral tradition and current legends. In this dream of life, they have brought their own lives and their own dreams into the dreams of their brothers. And they have made this with the spoken word, not with the written. With personal and familiar oratory, not with literature; with popular lore, the pueblo's spoken words-folklore as one says in English.

The spoken word! To the four gospels, the one attributed to John reminds us that, "In the beginning was the (spoken) Word," and that, "the spoken word was of God and God was the spoken word," and, "all things were made by it and without it no things were made." God, the Being of beings-Cause of causes-God, "the most excellent thing," thus we learned as children in the catechism presented to us by Father Astete, later mistakenly corrected-as I hear. The spoken word-that is the marvel even Faust did not see: that there is no separation of the spoken word from the deed ${ }^{16}$. And this is clear, for at the beginning of Genesis it says that God created the sky and the earth saying, "and the firmament will be called sky, and the light will be called day, and the darkness, night; and the dryness, earth, and the congregations of waters, sea." And later, he presented to Adam, the first man, all the living things of the ground and the birds of the sky that Adam might bequeath a word upon them. And what Adam called each living thing, is its name, its identity.

In the beginning was the Word. And in the end it shall be, for to the Word all shall return ${ }^{17}$. Each new Adam who arises in our world, each child, when he has

\footnotetext{
${ }^{15} 1$ ) It is also for this reason that Heidegger (Heidegger, 1968: p. 17) says "Socrates did nothing else than to place himself into... this current, and maintain himself in it. This is why he is the purest thinker of the West. This is why he wrote nothing." 2) Unamuno's use of a burial metaphor for writing here is probably associated with the tilling metaphor in the first paragraph, for he believes that the soul is grown upon the soil, which represents the existing community of speaking agents. I mention this as a metaphor to seek in other of his writings, when trying to revitalize his project.

${ }^{16}$ This comment strongly illustrates Unamuno's resonance with speech act theory, for it makes clear that our reality is a product of our utterances.

${ }^{17}$ The reader will see intimations of what Unamuno means by this at other locations in the essay. Clearly, he treats the spoken word as a power, indeed a spiritual power-the place where spirit resides. For that reason, to have one's name spoken by God is to have one's name spoken into history. All this has to do with Unamuno's philological commitments, and we can intimate its significance with an illustration: Unamuno would argue that the actions of Hector were a form of speech, articulated by Homer, and set into history in such a manner that, with each time we speak those words again (i.e. repetition) we give rebirth to the spirit of Hector and Homer within us. In this way, to be called into history, and to be recalled by history, is to be called into Being, as part of La Palabra (Unamuno's notion of the imminent, and emergent, and eternal God); and this is how we are granted immortality. This is an example of a complex idea in this essay that could be elaborated to good effect by rhetorical scholars, once the original text is in their hands.
} 
learned the name of a thing, knows it, for he has made it relate to himself; and he becomes a self by gathering these relationships with the named world ${ }^{18}$. In this way, the child creates the thing through the name. To question, "What is this?" is really asking, "What have we spoken into it?"-a way of relating to both its presence and the purpose our people give it. On the other hand, the child, not being what he is solely because he was caused ${ }^{19}$ (a thing, like other things made or even named to be as they are) but because he is also something internally-impelled toward a becoming, an end, what he names as his purpose also determines what he is. Consequently, when he is finished, he will leave to the ground some bones and to the air a name that is part of La Palabra (i.e., a name that has become immortalized in the speakable, historical-truth of a peopleRWK), one which, if he is fortunate, will be more durable than bones, more like bronze-Aere perennius (perennial bronze), said Horatio, and we explain this in our class - a name in the memory of the Creator's spoken word. For as the Creator brought the world into existence by naming it, so do humans increase that world by adding to it their own names, which they have eternalized by performing great and authentic deeds, especially in speech. Indeed it could even be said that history is nothing other than a tapestry woven together from all those bronzed names that legendary people have accomplished in their active lifetimes.

The spoken word and the name. "Holy is Thy name," we have been taught to recite. And this is because the name of God is God, is divine. "Give me your name," begged Jacob to the angel with whom he struggled, past the river crossing, until the stroke of dawn. "Give me your name!" came back. And Jacob gave him his name that he might be blessed. "Spirit without name!" sighed our poor poet Becquer ${ }^{20}$. And when our ancient comrade Fray Luis deLeon, a doctor of this very school, and whose bronze statue still exhorts us from the adjoining $\mathrm{Pa}$ tio de Escuelas, though his name will last longer than bronze, wanted to penetrate into the mysteries of the people's faith, he spoke with his pen Los Nombres de Cristo (The Names of Christ).

The name is the man! We are told in the same fourth Gospel how Christ in Jerusalem on the feast of the Passover didn't trust those who trusted in his name because of the miracles he performed, for he didn't need that kind of testimony. The man substantial and essential is the name, is the person. What is defining oneself but giving oneself a name, calling oneself? "I call myself thus," is as much

\footnotetext{
${ }^{18}$ For his dissertation, this author used the analogy of Robinson Crusoe naming island things (rope, spear, thatch) that could be situated within his life project, his world, as a castaway. Deleuze once used the same analogy to explain how coming into being implies coming into relationship with objects as named, that is to say objects made relevant (i.e., in relation) to world-historical actions.

${ }^{19} \mathrm{He}$ plays here with the Spanish word for "thing", cosa, to imply an etymological connection: causa/cosa.

${ }^{20}$ The soul that is entombed in death by virtue of the silence that it chose in life. The sigh is for the missed chance when another person passes by in silence, as the angel might have passed by Jacob. When a person passes by, we see the body, but if that body does not speak, we do not hear what is the essence of that body, and our souls remain untouched, except by imagination or phantasy, by the other. Jacob wrestled with the angel, that is to say, to hear in the angel's voice, and therefore beyond any superficial impression of the angel, the divine language of God.
} 
as saying, "I want to be thus." I make my name immortal because its spirit will breathe again in the breasts of those others who will utter it (as the spirit of these ideas will be repeated some day in the breasts of others) when I am gone. A man makes his name endure, and thereby makes himself into someone who is recognized, a person. After all, what else is the legal status of a person but the person's name? The name, the word, is the real action, the stated is the created ${ }^{21}$. The centurion of the gospel, knowing that Christ was capable of bringing forth action simply by speaking, asked Jesus to say but a word from a distance, without entering his house for he knew this was sufficient to heal his paralyzed servant ${ }^{22}$.

From this very place, three years ago, I opened the 1931/1932 academic year in the name of His Majesty, King of Spain -announcing his name and tasting it with fervor as my voice resounded in it. And this is because the spoken word is action. It is spirit, air, it is the articulated sound of breath. The sound makes the Verbo (the Living Word-RWK), la Palabra (authentic speech that manifests the imminent soul-RWK), which thereby makes the vision, the idea. The saintly fathers of the Greek Church called the Holy Spirit, the nominating breath, Saint Sophia of wisdom. And she made the Logos, the Word. Thus philosophy, the love of knowledge, germinates from philology, the love of saying.

And thus, when I had just been named for the first time rector of this school, in October of 1900, days after my other inaugural oration, I was entrusted with the charge of teaching, besides Greek speech and literature, what was initially called, "Comparative Latin and Castilian Philology" and later, "History of the Castilian Tongue." And this is the only discipline I taught when I returned from exile. Those bureaucratic, ritualistic almost liturgical titles of courses! But the second title fits the subject better. First, philology, the love of the word, of the name; and history can only follow, although ultimately one will see there is no difference. For history is a living tradition which remains and lives in the spoken word, in the moving word, in the name, always present. History is not script: it is not written documents, it is not writings - first it is the lecture, the lesson, the legend. The man exclusively committed to text doesn't exist historically-the man who exists is the man who also lives in the spoken word, who acts today, the man of the legend. And this is so much the case that those names of fiction,

\footnotetext{
${ }^{21}$ Rather than writing us a paper, here, Unamuno is offering flashes of ideas from which, ourselves, to think these papers. Here, in this meditation upon names, Unamuno is oscillating between the Greek notion of Logos and his adventure into his Spanish term of different but related meaning: la palabra, which will be discussed in a forthcoming essay. His interest in Greek makes him aware of the divine relationship between speaking and being, because of the first lines of Genesis, where God's Logos, God's "divine breath" (the meaning of the term) is able to create all things from the same breath that draws in life-create the heavens and the earth. Unamuno correspondingly argues that la palabra functions as the divine breath of humans, who make ideas directly from air, who spend their lifetimes transmuting into those ideas, so that they can slough off their skin at their death, now as eternal as the poet Becquer, living as the idea longer than bronze; all this described in these passage as a compulsive yearning to give la palabra and to receive it.

${ }^{22}$ This seems to be a play on the gospel of the pagan centurion who asked Christ's intercession on behalf of his dying daughter. While Marias mentions that Unamuno's work is "crisscrossed by philosophical and religious errors," (Marias, 1966: p. vi) it is not necessarily the case that Unamuno got the story confused, for he regularly reworked narratives, Christian and otherwise, to achieve literary effects.
} 
those creations of poetic human speech, have a greater historical existence than those who have been buried without name.

My discipline was "History of the Tongue," not of literature, not of the written words when they don't respond to the spoken. It has been said that all genuine Castilian writers are orators in their writing. Better to be a speaker in one's writing than a writer in one's speaking. Not to speak like a book, but to write a book that speaks, as Saint Theresa spoke with her pen, authentically. Rhetoric? And why not? If you would instead say grammar, then you must recall how boldly it seeks to supervise us with its $\gamma \rho \alpha \dot{\mu} \mu \alpha$-grama, which refers to its rule-driven and scripted character ${ }^{23}$. Rhetoric, sounding, speaking - as in the moment of creation-brings to life. It is alive, spontaneous, immediate. Whereas the written always comes from a dead past.

Of course the document is inevitable. And, much less damaging, we now have the phonograph, which initiates an archive of the spoken word, or perhaps (ouch!) of the word kept in a can ${ }^{24}$. In my own case, at my second inaugural oration, I would have preferred that it was truly oration, oral I said - not recited, but I was obligated to subject myself to the academic liturgy; and worse, under the danger of deciphering shorthand.

Verba volant, it is said ${ }^{25}$, but I say the word itself is flight, and already even here it flies as a living and a thinking, without allowing itself to be caged or embalmed.

History? I said it to your fathers from this same place thirty-four years ago, and I repeat it today. History is that which takes place around you: yesterday's riot, today's crop, tomorrow's feast. It is only in the here and now that we understand the there and yesterday, and not the inverse; only the present is key to the past, and only that which is immediate and proximate provides a pathway to the remote. That which does not rest, in one manner or another, in the presenteither flowering in the present or polished as another precious historical stone in the present's rock garden - was never anything more than a fugitive apparition. The present is the effort of the past to become future, and that which doesn't tend toward tomorrow ought to remain in the forgetfulness of yesterday.

And today, to repeat my words from 1900, I have to say that the past brings strength to the lived by making it a future-to-be-lived, as a tradition, by marking ${ }^{23}$ Unamuno understood that a spoken language develops freely and flexibly across millennia, only to be much-later hobbled by the imposition of rules that typically follow the development of writing. Because he is interested in the interpersonal and interpsychic vitality of spoken language, he privileges the morphologies (the various shapes) of spoken and naturally developed speech in communities, not the artificial speaking that is bound by the straight-jacket of a rigorous and typically national rule system that crushes both spontaneous speech diversity and speech's vital transformations.

${ }^{24} \mathrm{Here}$, Unamuno is channeling the concerns expressed by Socrates, late in the Phaedrus dialog, regarding writing and other imitations of speech, adding the phonograph as a commentary on new technology. ${ }^{25}$ Unamuno refers to the Roman saying, Verba volant, scripta mament- "Spoken words fly away, the written lasts." Unamuno wants to challenge the expression's common understanding that spoken words are as fleeting as dust in the wind. In his own characterization here, the spoken word is treated as a winged-idea with the power to fly amongst listeners, an analogy which is quite like the story of the Holy Spirit which arrives as a dove, illuminating the spiritual life of the disciples, a point he makes moments earlier in relation to Santa Sophia. 
our progress and destiny. And this I applied then to the history which I was beginning to profess, to that of the spoken language. Spoken language, I say. You might superficially grasp how a language can live but you will never grasp this idea with active and creative comprehension unless you open your ears to the sounds of your own region, unless you direct yourself faithfully and attentively to the idioms of the populace - to what they say and to their sayings; to all that so-called barbarism that has been customarily kept outside intellectual consideration, thereby making the tongue a product of a literary pact subject to academic prescription. Thus as I have been saying, I began, through the Castilian language, to search for Spain, as if I were on a voyage of discovery ${ }^{26}$. Discovering Spain. For if it is true, as many people tell us, that the rustic laborer with his traditional plow merely turns the dusty layer that covers-up the true wealth of our Spanish subsoil, then it may also be true that in Spain's spiritual subsoil, in the disregarded underground of its daily collective life, lies the possibility of a renaissance, while we continue scratching with our critiques and our apologetics only upon the surface of its glorious mounds and historical layers. You must discover our people in their living history, in their work, hope, prayers, suffering, joy.

Indeed, this idea compels me to set aside my earlier notion that the experiences raised to significance by the nation are the essence of the historical. What in one of my essays, En torno al catecismo, I called "intra-history" is history itself, its core. And in relation to this idea that true history is the living history of its people, but in reference to the tongue, Capmany has already said that the greater part of Castilian language is buried in the verbal entrails of the small Spanish towns. Yes, I am proposing that we disinter it, but not in order to disinherit it.

And this is what I have been doing here in my official chair with my spoken word, as I have in my public actions in all of Spain with my written word, during these thirty-four years, and even before that. I have looked for the national historic tradition, the fountain of its progress and destiny and even of its revolutions, in the richness of speaking, of the language; struggling to investigate it to its core, to dig it up. And I did this because all the civilization, all the economy, all the justice, all the art, all the learning, all the religion of Spain is buried in the recesses of its language and beating in the marrow of its bones.

Loving is feeling, feeling is thinking, and thinking is speaking, speaking to oneself and to others, and with God if one can. Co-existing is co-feeling, and co-feeling is understanding, one person comprehending another. And this social, political, and religious co-existence, this understanding which is one's homeland, one's nation, is even more precious now in this crisis of national, political rebirth -of rebirth I called it one day. It is an understanding we must share but equally experience within our separate hearts.

\footnotetext{
${ }^{26}$ Unamuno is playing with a Spanish word here that carries a closer association with "uncover" than it does in English, where uncovering is more closely associated with digging, the analogy around which he grounds this essay.
} 
True community is born of spiritual communion, oral communion, and a shared understanding of heart-felt national community-inter-related and independent at the same time. The tongue which truly lives must be individual, national, and universal. A dialect suggests a dialogue - a conversation, and an agreement. And even a controversy, which is a style of dialect, carries structures of agreement within its discord. Each of us must form, and reform, and transform his proper dialect, individual and regional, his proper idiom-an idiom which I want to say is proper to him-inside of the common idiom and enriching it by enriching himself within it. And this is why, students of Salamanca, I have been these years trying to teach you in the manner of Socrates, the very tongue which you speak; to bring you to clear consciousness of it, to help you to give it birth, so that I could relearn it from you, and all of us together, could penetrate to the core of this Castilian language that makes our souls Spanish. The point is not to dissect the language - though that sort of thing has its uses - but to recreate it. The point is to illuminate its living source, which for the greater part is buried.

And this is living philology, a love for speaking and not exclusively for erudite investigation of seminal technique, which is essentially nothing more than an indispensable preparation for the other. As criticism is preparation for poetry, so understanding is preparation for creation. But what good is understanding if there is nothing created? Criticism itself, when it is living criticism, is recreation and a result of poetry, as if polishing diamonds with their own powder, testing them against the metaphors, making them powder, and classifying and studying them in terms of their powder. With this kind of philology, with this love for the language which is yours and mine, which is national and individual (individual and universal because it comes to the same) with this kind of philology I repeat, we will recover the spiritual patrimony of our historic race, of our culture. The weight of the centuries, enclosed in secular metaphors, strengthened by the spirit, the verbal breath made by the grace of God, the Word Most High, has fashioned us Spaniards of Spain. The beliefs that console us, the hopes that drive us toward future pledges, the dreams that maintain us in the foot march of history, toward the fulfillment of our destiny, even the discords that by dialectical and antithetical paradox, unite us in intimate civil war, are rooted in the common language.

Each language carries implicitly, better incarnates in itself, a conception of the universal life and with it a sentiment-one feels with words-a consensus, a philosophy, a religion. Our language too carries that, and reaching to that philosophical core, is philology, is the history of the language, of the tongue. What is called philosophy in general-what is it but the universal thinking about humanity, incarnate in the word? Not syllogistic definition, but narrative description; not dogmas, but legends, personal stories.

The genuine thinkers are the poets. The great universal religions live in the names of saints and prophets, not in abstract ideas. The fable explains itself by 
itself, and exceeds any moral extracted from it. And it is foolish to demand that we not teach our sons the vision, the conception, and the sentiment of the world which surrounds them in the sound of the speech which they learn from the mouth of their mothers with the milk that they suck from her breast. It is our world. No belief, no dream, no legend, no myth, which has really been alive can ever die. And one cannot be Spanish if he does not have a loving acquaintance with all those who created Spain.

The child is born innocent, and its consciousness must thereafter be made in the bosom of its community, which is its spiritual womb. Should one respect the conscience of a newborn? But how, for it doesn't have one! That will only come after it has been given the maternal speech that is the spiritual blood, with all the vision and all the world view belonging to this deep-language we call culture. Objective (i.e., imposed) teaching? ${ }^{27}$ But what is objective? The individual is certainly a social product, but society is a human and an individual product, and man a rational, civil animal - a political animal according to Aristotle. Rational—of reason: ratio and this from reri, speaking, which means verbal: man is the animal that speaks. A Spaniard who does not think in the Spanish languageunless he thinks in some other language in which case he may not be Spanish-is not thinking, is not rational. And to think in the Spanish language is to think what this language has thought and to believe what it has believed. Because a language, the soul of a community, thinks and believes. And we can't say that it doesn't feel because it feels in thoughts-the feelings are thoughts that run all through us. Others are animal sensations, not rational, not human, not personal. And it is sufficient to notice, given what I have said about a spoken language, the deep cultural tradition of so many who neither read nor write.

And this attempt to dig up the roots of our Castilian language led me to explore how they are bound and joined with the roots of other Romance languages of our Iberia, with other dialects of the common Roman tradition, the Latin language. And thus I saw myself called to attend and represent the diverse speakings of our Iberia and their reciprocal influences. In my university classes, I initiated the study of Catalan and Valencian, of Gallician and Portuguese, and still others. From my courses, students have left more than a little enamored with the speaking and the literature of Catalan-Lemosin and Gallician-Portuguese. From such differences, integration arises.

I hope, and I said it on an occasion particularly solemn for me at another public forum, that the future common language of greater Spain, of our Iberia, will make itself from the recasting, better the uniting, of our languages, so that we won't have to be translators for others and thereby traitors to ourselves. Such has been my labor, the one from which I take my official departure today, and which obligates me on this occasion to stand before you with this self-reckoning. Such has been my work. I initiated it without a program, without a precise definition. For as Goethe so appropriately said with the appropriateness of a poet, to pre-

${ }^{27} \mathrm{He}$ is concerned here with the idea of teaching as imposing an ideology-the notion we tell you what to think and then you think it, discussed in the prefatory remarks. 
face a work with a definition in any discipline is to miss the point that in order to reach the definition one first has to complete the work. What I say to you today is not a prologue, but an epilogue; not a program, but an epigram or a metagram, if you like. Not what I intend to make, but what I have already made. This is my work. Should this be dismissed as a mere 'playing with words'? Well, in just this way Quevedo, our great aphorist, our great wordsmith, journeyed to the bowels of the Castilian language, provocatively investigating within it the soul of the Spanish people. As did Calderon, and Gracian, and the mystics, and so many others. This was my work, and also my political work. Political, which is to say civil-for civilization. And I am not speaking of the strictly political discords which agitate our university lives. Will someone say that there is no room for politics within the university? Well, it depends on what one calls politics and what one calls the university. Factions? No! Integrity? Yes! Sad and decaying will the future of Spain be if these civil temples of our cultural heritage are impoverished and obscured by "professional" faculty members who are intent on making a living that will not survive in history ${ }^{28}$.

In each special branch of knowledge, its history is its living essence; and the other, the technical or codifying function that it serves, is quite often a death certificate. There are those who make themselves martyrs, that is, witnesses of their culture. The martyr gives his life for the spoken word, for the freedom of the spoken word. He gives his life, but he does not take the lives of others; he allows himself to be killed, but he doesn't kill. In recollecting this I hope I have made visible the thread which fashions the continuity of all my work, revealing that this man of so much supposed versatility has followed in his academic profession, as much as in his general life, a clear and definite path.

Today I am honored, yet I believe that your homage is really directed to the work I have described. And, because I know that homage comes from the word hominem "of man" (always I turn to philology) your homage is something that I can also accept when it is directed at me. For indeed, I have tried to complete my mission, my destiny: to become the man that I am within this very work-a university man of the universal Spain whose name I spoke out not only to other nations who shared our linguistic heritage, such as those great portions of America which were conquered and other regions of the world, but also to others that feel and think in different languages. Words give us the power to conquer truly. More has been gained by the Spanish word that flowed from the pen of Cervantes in his Quixote, son of the spoken word, than was gained by Juan of Austria with his sword in the battle of LePanto. I have tried to come to know myself better in order to know my people better, mainly through the mirror of the language in the hope that this will make it possible for other peoples to know us better, for knowledge leads to love, and above all in the hope of being better known by God: that is, of being acknowledged by Him so that we may live in his memory, which is History-divine thought yoked to this earth by our human flesh.

${ }^{28}$ Here is a cautionary reminder for all of us who exist within an intellectual environment that weighs a scholar's contribution by counting publications. 
And my last words as I take my leave, school fellows, masters and students, students all: have faith in la palabra, the spoken word, which is a living thing; be men of speech, men of God, the Supreme Thing and Spoken Word Most High, and let us hope that God will acknowledge all of us in Spain as his own. And let us go forth, in our studying, working, speaking, creating ourselves and Spain, its history, its tradition, its life-course, its adventure!

Now I will say adios to you, but I will say it to remind you of how this very word has come to us from an earlier way of speaking in which we wished each other farewell, blessing that we might go by, with, and for God. And, therefore: A-Dios!

Don Miguel De Unamuno Y Jugo ${ }^{29}$.

\section{Conclusion}

Unamuno is studied across various disciplines and in many languages. He is also remembered and studied in Spain as a historical figure. Consequently, it is somewhat ironic that this monumental, $20^{\text {th }}$ century intellectual, nominated for a Nobel Prize in literature, suffers the absence of an English translation of this critical document in his ouevre. While it is available in Spanish in his Collected Works (Unamuno, 1958c) and placed at the end of this essay as an Appendix for referencing, the present article will eliminate the absence of an English equivalent-moreover the remarks set out in the prefatory essay will play an instrumental role in the development and understanding of both Unamuno's philosophy and rhetoric.

\section{Conflicts of Interest}

The author declares no conflicts of interest regarding the publication of this paper.

\section{References}

Burke, K. (1966). Definition of Man. In Language as Symbolic Action: Essays on Life, Literature and Method (pp. 3-24). Berkeley, CA: University of California Press.

Doyle-McCarthy, E. (2017). Emotional Lives: Dramas of Identity in an Age of Mass Media. New York: Cambridge University Press.

Ferrater, J. (1962). Unamuno: A Philosophy of Tragedy (Translated by Silver, P.). Berkeley, CA: University of California Press.

Finkelstein, S. (1968). Sense and Nonsense of McLuhan. New York: International Publishers.

Grotstein, J. S. (1977). Splitting and Projective Identification. New York: Jason Aronson Inc. Publishers, Rowan and Littlefield.

Heidegger, M. (1968). What Is Called Thinking (Translated by Glenn Gray, F. and Wieck,

${ }^{29}$ By writing "A Dios" at the end, Unamuno employs a synechdoche that contains the entire speech he has given. Effectively, it is both a wish and a call-to-adventure to all who hear it-specifically that they might, in keeping with the theme of this, his last lecture, advance themselves along the intellectual's pathway into the light of God, the eternal and imminent La Palabra. The idea is developed from Socrates notion that all philosophy is preparation for death. Finally, the translation is based upon (Unamuno, 1958c) in the references. 
F.). New York: Harper \& Row Publishers.

Hughes, R. (1978). Education and the Tragic Sense of Life: The Thought of Miguel de Unamuno. Educational Theory, 28, 131-138. https://doi.org/10.1111/j.1741-5446.1978.tb00803.x

Kenny, R. W. (2010). Beyond the Elementary Forms of Moral Life: Reflexivity and Rationality in Durkheim's Moral Theory. Sociological Theory, 28, 215-244. https://doi.org/10.1111/j.1467-9558.2010.01371.x http://www.interscience.wiley.com/journal/soth

Kenny, R. W. (2019). From Metanoia to La Palabra: Cultural Mythology as a SenseMaking Act in Unamuno's Last Oration. (Forthcoming)

Lacy, A. (1967). Miguel de Unamuno: The Rhetoric of Existence. The Hague: Mouton Press.

Mannheim, K. (1952). Essays on the Sociology of Knowledge. New York: Oxford University Press Inc.

Marias, J. (1966). Miguel de Unamuno (Translated by López-Morillas, F.M.). Cambridge, MA: Harvard University Press. https://doi.org/10.4159/harvard.9780674431355

Ortega y Gasset, J. (1929). The Revolt of the Masses (Authorized and Anonymous Translation). New York: W. W. Norton \& Company Inc.

Ortega y Gasset, J. (1956). The Self and the Other (Translated by Trask, W.R.). In The Dehumanization of Art and Other Essays (pp. 161-187). Garden City, NY: Doubleday Anchor Books.

Pei, M. (1965). The Story of Language. New York: J. B. Lippincott Company.

Philipsen, G., and Albrecht, T. (1997). Developing Communication Theories (pp. 119-156).

Portillo, L. (1984). Unamuno's Last Lecture. In Selected Works of Miguel de Unamuno: Volume 2: The Private World (Translated by Kerrigan, A., Lacy, A. and Nozick, M., pp. 263-271). Princeton, NJ: Princeton University Press, Bollingen Series LXXXV.

Richards, I. A., \& Ogden, C. K. (2007). The Meaning of Meaning: A Study of the Influence of Language upon Thought. Boston, MA: Houghton-Mifflin Publishers.

Rudd, M. (1976). The Lone Heretic: A Biography of Miguel de Unamuno y Jugo. New York: Gordian Press.

Unamuno, D. M. (1945). Perplexities and Paradoxes (Translated by Gross, S.). New York: Philosophical Library. https://doi.org/10.2307/25292713

Unamuno, D. M. (1958a). Oraccion Innaugural del Curso 1900-1901, en la Universidad de Salamanca: Alocucion exhortiva. In Obras Completas (Vol. 7, pp. 493-504). Madrid: Afrodision Aguado, S.A.

Unamuno, D. M. (1958b). Conferencia En La Sociedad De Ciencias, De Malaga, EL 23 De Agosto De 1906. In Obras Completas (Vol. 7, p. 713). Madrid: Afrodision Aguado, S.A.

Unamuno, D. M. (1958c). Discurso Leido En La Solemne Inaugracion del Curso Academico de 1934 a1935, En la Universidad de Salamanca, El Dia 29 Setiembre de 1934, al Ser Jubilado Como Catedratico. In Obras Completas (Vol. 7, pp. 1077-1088). Madrid: Afrodision Aguado, S.A.

Unamuno, D. M. (1984). The Tragic Sense of Life in Men and Nations. Princeton, NJ: Bollingen Press. 


\section{Appendix}

The following Spanish text of Unamuno's speech is added for reference purposes. While a copy is open-source available

(https://docplayer.es/89286218-Universidad-de-salamanca-discurso-leido-en-la-so lemne-inauguracion-del-curso-academico-de-1934-a-1935-por-el-doctor.html, that version is haunted by numerous machine errors, which I have corrected. The text has appeared in various forms in Spanish, the most commonly available one being listed in the references for this publication.

Discurso Leido En La Solemne Inaugracion del Curso Academico de 1934 a1935, En la Universidad de Salamanca, El Dia 29 Setiembre de 1934, al Ser Jubilado Como Catedratico

Compañeros maestros y discipulos, estudiantes todos:

QUE de recuerdos, lejanos unos y otros recientes, al venir de despedida, a repetirme una vez más aquí, en este paraninfo, caja de resonancia de tantos de ellos! Vengo a repetirme, repito, a renovarme. Una vida espiritual entrañada es repetición, es costumbre, santo cumplimiento del oficio cotidiano, del destino y de la vocación. Día a día he venido labrando mi alma y labrando las de otros, jóvenes, en el oficio profesional de la enseñanza universitaria y del aprendizaje. Que enseñar es, ante todo y sobre todo, aprender.

Comencé mi primer curso-de Lengua y Literatura griegas, no más entonces-en 1891, hace cuarenta y tres años, venido de mi nativa Vizcaya a robustecer en la alta meseta, toda ella cima, los huesos y la piel que el aire del mar y de la montaña nativos me habían fraguado. Y durante cuarenta y tres cursos-quiero contar entre ellos los del destierro a que me sometí por defender la libertad de la palabra y en que con mi ausencia creo que enseñé-he venido colaborando aquí, en esta Universidad, a la forja de la España universal y eterna. Leí, aquí mismo, el discurso inaugural-"alocución exhortativa" le llamé-de 1900, y poco después, aquel mismo año, se me elevó a mi primer rectorado de esta escuela de la tradición española.

Debería hoy y aquí callar mi acción extrauniversitaria, sobre todo la política. Dudo que me sea hacedero, porque, ¿es que el magisterio público se ejerce sólo en el aula oficial? En aquella "alocución exhortativa"-que no disertación investigativa-de hace treinta y cuatro años - parece como si el tiempo se remansara haciéndose eternidad histórica-os decía, jóvenes estudiantes-o a vuestros padres, que viene a ser lo mismo: “Ojalá viniéseis todos henchidos de frescura, sin la huella que os han dejado quince o veinte exámenes, y trayendo a estos claustros no ansia de notas sino sed de verdad y anhelo de saber para la vida, y con ellos aire de la plaza, del campo, del pueblo, de la gran escuela de la vida espontánea y libre." Os lo decía al cumplir mis treinta y seis años; os lo repito hoy al cumplir mis setenta. Y venir a examinarme a mi vez.

$\mathrm{Al}$ ensenar, y aprendiendo a ensenarlas, la lengua y las letras del pueblo heleno, eternamente joven y eternamente anciano-la antigüedad es la niñez de los pueblos y la niñez es la antigüedad del alma-fui retemplando mi espíritu re- 
belde a disciplina. Tenía que disciplinar a discípulos. Y así llegó a asistirme el ánimo simbólico de Sócrates, el hijo de la partera, el gran partero que se llamó a sí mismo, el que asistía a la mocedad ateniense a que se diera a luz, a su propia conciencia, la visión del mundo y así la recreara recreándose en ella. Y esto por la palabra. Que Sócrates, como el Cristo, el Verbo, no nos dejó escrito nada; no se enterró en letra.

He dicho alguna vez, con escándalo acaso de ciertos pedantes, que la verdadera universidad popular española han sido el café y la plaza pública. Los usureros de la investigación y avaros de ella suelen quejarse del ingenio que se ha derrochado en España en peñas de casino o de café, en tertulias, en accidentales reuniones de amigos. Lo estiman perdido. ¿Perdido? ¿Por qué? Esos ingénuos e ingeniosos espíritus socráticos, tan castizos, no nos han legado sus nombres, pero han conservado y enriquecido la tradición oral y las leyendas corrientes. Han hecho soñar y vivir en el sueño a sus hermanos. Y lo han hecho con la palabra, ya que no con la letra. Con oratoria familiar y privada, no con literatura; con doctrina popular, folklore, que en inglés se dice.

¡La Palabra! Al principio del cuarto Evangelio, el llamado de San Juan, se nos dejó dicho que "en el principio fué el Verbo", la Palabra, y que "la, y Palabra estaba cabe Dios, y Dios era la Palabra", y "todo se hizo por ella y sin ella no se hizo nada de lo hecho". Dios, la Cosa de las cosas y Causa de las causas-Dios, "cosa mas excelente", así aprendimos de niños en el Catecismo del P. Astete, luego desacertadamente corregido, me dicen-la palabra, que es el hecho, pese a Fausto. Que no hay trecho de lo dicho a lo hecho. Y en el principio del Génesis, que Dios creó el cielo y la tierra diciendo, y llamó al firmamento cielo, y a la luz, día, y a las tinieblas, noche, y a la seca, tierra, y a la congregación de las aguas mar. Y luego, que llevó a Adán, al primer hombre, todos los vivientes de la tierra y las aves del cielo, para que les diese nombres, y aquél con que llamó a cada viviente, ése es su nombre.

Y a cada nuevo Adán que llega a nuestro mundo, a cada niño, cuando se le ha enseñado el nombre de una cosa la ha conocido, la ha hecho suya y una, la ha hecho cosa con el nombre. Preguntar: “¿qué es eso?” quiere decir: “¿cómo se le llama?" En el principio fué la palabra. Y en el fin lo será, pues a ella ha de volver todo. Que no es sólo un por qué, una causa, cosa inicial, sino un para qué, un fin. Y es un por que, por ser un para qué. El hombre deja a la tierra unos huesos y al aire un nombre, un nombre en la memoria de la Palabra creadora, en la Historia: tejido de nombres; un nombre-si logra buena ventura-más duradero que los huesos, más que el bronce. Aere perennius, que dijo Horacio, a quien explicamos en nuestras clases.

¡La palabra y el nombre! "Santificado sea el, tu nombre" se nos ha enseñado a rezar. Y es que el nombre de Dios es Dios, es divino. “Díme tu nombre!”, suplicaba anheloso Jacob al ángel con quien luchó, pasado el vado de Jacob, hasta el rayar del alba. “Díme tu nombre!” Y Jacob le dijo el suyo para que le bendijera. “¿Espíritu sin nombre!”, suspiraba nuestro pobre poeta Bécquer. Y cuando nues- 
tro antiguo compañero el Reverendo Padre Maestro Fray Luis de León, doctor de esta Escuela, y cuyo bronce aún nos amonesta en su nombre, más duradero que él, desde el adjunto Patio de Escuelas, cuando quiso zahondar en los misterios de la fe de su pueblo, dijo con su pluma los "Nombres de Cristo".

El nombre es el hombre. Se nos cuenta en el mismo cuarto Evangelio cómo el Cristo, al estar en Jerusalén en la fiesta de Pascua, no se confió en los que confiaban en su nombre por las señales que hacía, pues no necesitaba que atestiguaran acerca del hombre. Pero el hombre sustancial y esencial es el nombre, es la persona. ¿Qué es definirse-¡lo que se ha pedido esto!- sino darse nombre, llamarse? "Me llamo así" quiere decir: "quiero ser así". Y lo que se inmortaliza es el nombre, que es la piel espiritual y el pecho por que traspira y aun respira el alma. El hombre hecho nombre queda hecho persona. Y ¿qué es la llamada persona jurídica sino un nombre? El nombre, la palabra es la verdadera acción, el dicho es el hecho. El centurión evangélico, sabiendo que con sola su palabra ordenaba la acción, pedía a Jesús que dijese una sola palabra y a distancia, sin entrar en su casa, para sanar a su criado perlático.

Desde aquí mismo, hace dos años, al abrir el curso 1932 a 1933, lo abrí en nombre de Su Majestad España - en su nombre y paladeándolo con fervor al pronunciarlo-y mi voz resonó en ella. Y es que la palabra es acción. El espíritu, la respiración sonora, el són, hacen el Verbo, la Palabra, y la palabra hace la visión, la idea. Los santos padres de la Iglesia griega llamaron al Espíritu, al Soplo nominador, Santa Sofía, Santa Sabiduría. Y ella hizo el Logos, el Verbo. Que la filosofía, el amor del saber, brota de la filología, del amor del decir.

Y así, apenas nombrado por primera vez rector de esta Escuela, en Octubre de 1900, días después de mi otra oración inaugural, se me encomendó, además de la enseñanza de la lengua y literatura griegas, la de lo que se llamó primero "Filología comparada del latín y castellano" y después "Historia de la lengua castellana”, y es la sola disciplina con que me quedé a la vuelta de mi destierro. ¡Denominaciones burocráticas, rituales, litúrgicas casi! Pero la segunda condice ya mejor con la cosa. Primero, filología, amor de la palabra, del nombre; después, historia. Y en resolución, lo mismo. Porque la historia, la tradición viva, queda y vive en la palabra, en el verbo, en el nombre, siempre presente. Historia no es letra, no es documento escrito, no es escritura, antes bien lectura, lección, leyenda. No existe históricamente el hombre que se queda en la letra, sino el que vive en la palabra, el que obra hoy por hoy, el de leyenda. Y hasta los nombres de ficción, las creaciones de la palabra humana, los de poema, existen históricamente más que los enterrados sin nombre.

Era mi disciplina "Historia de la lengua", no de la literatura, no de la letra mientras no responda a la palabra. Se ha dicho que todo castizo escritor castellano es un orador por escrito. Mejor que ser un escritor por habla. No hablar como un libro, sino que el libro hable como Santa Teresa hablaba con su pluma, como un hombre. ¿Retórica? ¿Y por qué nó? Lo malo de la gramática es lo que tiene de grama, de letra. La letra mata; el espíritu, el son, vivifica. Y aun así es 
inevitable el documento. $\mathrm{Y}$ menos mal que, gracias al fonógrafo, se empieza a pensar en el archivo de la palabra. Mas, jay!, de la palabra acaso en conserva de lata. Esta misma mi segunda oración inaugural habría yo preferido que fuese verdadera oración, orada, dicha-no recitada-pero me he tenido que rendir a la liturgia académica, y más ante el amago de la taquigrafía.

Verba volant; pero la palabra misma es vuelo, y deja su vuelo al aire el pensamiento vivo sin dejarse enjaular y menos embalsamar.

“¿Historia?-decía a vuestros padres desde aquí mismo, hace treinta y cuatro años, y os lo repito hoy-Historia es lo que en torno vuestro ocurre, el motín de "ayer, la cosecha de hoy, la fiesta de mañana." Sólo con el hoy aquí entenderéis rectamente el ayer allí, y no a la inversa; sólo el presente es clave del pasado y sólo lo inmediatamente próximo lo es de lo remoto. Lo que no descanse de una manera o de otra en el presente, ya a flor de él, ya en su lecho de roca sedimentado, no fué más que fugitiva apariencia. Es el presente el esfuerzo del pasado por hacerse porvenir, y lo que al mañana no tienda, en el olvido del ayer debe quedarse.

Y hoy, al repetir mi lección de antaño, he de deciros que lo viviente es el esfuerzo de lo vivido por hacerse porvivir, de la tradición por hacerse progreso y ventura. Y lo aplicaba entonces a la historia de que empezaba a profesar, a la de la lengua. “¿Lenguas?-_ecía-. Jamás comprenderéis con comprensión activa y fecunda, no pasiva y estéril, cómo una lengua vive mientras no abráis los oídos a la que en vuestro derredor suena, prestándolos atentos y fieles a los modismos del vulgo, a sus dichos y decires, a todo lo que como a barbarismo indigno de atención han solido desechar los que hacen del lenguaje un producto de pacto literario sujeto a académica prescripción. Así os decía, y empecé en la lengua castellana a buscar a España, a tratar de descubrirla, a descubrírnosla. Descubrirnos a España-digo, os decía-, porque si es cierto, como por muchos se nos asegura, que su mayor riqueza material en su subsuelo se esconde esquiva mientras araña el la briego con el tradicional arado la ligera capa que la recubre y vela, en su subsuelo espiritual también, en los no escudriñados soterraños de su cotidiana vida colectiva yace tal vez el venero de su renovación futura mientras seguimos arañando con nuestra crítica y apologética en las humosas glorias de su capa histórica. Tenéis que descubrir a nuestro pueblo tal como por debajo de la historia vive, trabaja, espera, ora, sufre y goza.

Sólo tengo que rectificar ahora el mal sentido que entonces daba, erradamente, a lo histórico. Lo que en uno de mis ensayos de "En torno al casticismo" llamé la intrahistoria es la historia misma, su entraña. Y en cuanto a la lengua, ya Campmany decía que lo más del romance castellano está enterrado en la entraña verbal del pueblo. Hay que desenterrarlo, pues, mas no para desterrarlo.

$\mathrm{Y}$ es lo que he venido haciendo en mi cátedra oficial aquí, con mi palabra hablada, en mi acción pública en toda España, con mi palabra escrita, durante estos treinta y cuatro años, y aun desde antes. Buscar la tradición histórica nacional, fuente de su progreso y ventura, y hasta de sus revoluciones, en el tesoro 
del habla, del lenguaje; bregar en el escudriño de sus entrañas, a desentrañarlas. Toda la civilización, toda la economía, todo el derecho, todo el arte, toda la sabiduría, toda la religión española están ahincados en los entresijos de su lenguaje y hasta laten en el tuétano de sus huesos.

Querer es sentir, sentir es pensar, y pensar es hablar, hablarse uno a sí mismo y hablar a los demás, y con Dios, si lo logra. Convivir es consentirse, y consentirse es entenderse unos a otros, comprenderse. $Y$ esta convivencia social civil y religiosa, esta comprensión, que es la patria, la nacionalidad, nos es más preciosa ahora, en esta crisis de renacimiento-de renación la llamé un día-y que nos entendamos y comprendamos unos a otros y cada cual a sí mismo.

La verdadera comunidad nace de comunión espiritual, verbal, y ésta de entendimiento común, de verdadero sentido común nacional. Común y propio a la vez. La lengua viva, de veras viva, ha de ser individual, nacional y universal. Dialectal, es decir, de diálogo, de conversación y de concordia. Y de dialéctica. Y hasta de polémica, que es, a su modo, una concordia entre discordias. Cada uno ha de formarse y reformarse y trasformarse su propio dialecto, individual y regional, su propio idioma-idioma quiere decir propiedad-dentro del idioma común, y enriquecerse de él y enriquecerlo enriqueciéndose. Y he aquí por qué, estudiantes salmantinos, he venido estos años esforzándome, socráticamente, en enseñaros a aprender la misma lengua que hablábais, a daros conciencia clara de ella, a que la diérais a luz y aprenderla yo así de vosotros, y todos de consuno a desentrañar el romance castellano que nos está haciendo el alma española. No a disecarlo técnicamente-lo que es meritorio-sino a recrearlo. A alumbrar su vivo manadero, en gran parte soterraño.

$Y$ esto es filología viva, amor de habla, y no exclusivamente erudita investigación de seminario técnico, que no es, a lo sumo, sino una indispensable-que no podemos ni debemos dispensarnos de ella-preparación para lo otro. Como es la crítica preparación para la poética, la comprensión camino de creación. ¿Para qué comprender si no se ha de crear? La misma crítica, cuando es viva, es recreación y es desecho de poesía; que así como se pulían diamantes con polvo de ellos, se ensaya a las metáforas, se las pule-y clasifica y estudia-con polvo de ellas. Con esa filología, con ese amor del habla común y propia a la vez, nacional e individual a la par, individual y universal, que es lo mismo, con ella cobraremos el heredado patrimonio espiritual de nuestra raza histórica, de nuestra cultura. A presión de siglos, encerrado en metáforas seculares, alienta el ánimo, el espíritu, el soplo verbal que nos ha hecho lo que por la gracia de Dios, la Palabra suma, somos: españoles de España. Las creencias que nos consuelan, las esperanzas que nos empujan al porvivir, los empeños y los ensueños que nos mantienen en pie de marcha histórica a la misión de nuestro destino, hasta las discordias que, por dialéctica y antitética paradoja, nos unen en íntima guerra civil, arraigan en el lenguaje común.

Cada lengua lleva implícita, mejor, encarnada en sí, una concepción de la vida universal, y con ella un sentimiento-se siente con palabras-, un consenti- 
miento, una filosofía y una religión. Las lleva la nuestra. Y el enquisar, el desentrañar esa filosofía, es obra de la filología, de la historia de la lengua. La llamada filosofía en general ¿qué es sino la historia del pensamiento universal humano encarnado en la palabra? No definición silogística, sino descripción narrativa; no dogmas, sino leyendas, personas.

Los genuinos pensadores son los poetas. Las grandes religiones universales viven en nombres de personas, no de ideas abstractas. La fábula se explica por sí misma, y sobra la moraleja. Y es locura pretender que no se enseñe a nuestros hijos la visión, la concepción y el sentimiento del mundo que se encierra en el son del habla que aprenden de la boca de sus madres con la leche que maman de sus pechos. Es nuestro mundo. Ninguna creencia, ningún ensueño, ninguna leyenda, ningún mito, si fueron vivos, mueren. $\mathrm{Y}$ no será español quien no conozca, y con amor, los que fraguaron a su España.

El niño nace inconciente, y se hace su conciencia en el seno de su pueblo, que es como su matriz espiritual. ¿Respetar la conciencia del niño? Pero ¡si no la tiene! Recibe el habla materna, que es la sangre del espíritu, y con ella toda la visión y toda la concepción del mundo que ella encierra. ¿Enseñanza objetiva? ¿Y qué es objeto? El individuo es, ciertamente, un producto social; pero la sociedad es un producto humano e individual, y el hombre un animal racional-civil, político le llamó Aristóteles-. Racional—de razón, ratio, y este de reri, hablarquiere decir verbal: el hombre es un animal que habla. El español que no piense en lengua española, si es que no sabe otra, no es que no sea español, es que no piensa, no es racional. Y pensar en lengua española es pensar lo que esa lengua ha pensado, creer lo que ha creído. Porque una lengua, alma de un pueblo, piensa y cree. $\mathrm{Y}$ no digamos que no siente, porque se siente en pensamiento-los sentimientos son pensamientos en conmoción-. Lo otro son sensaciones animales, no racionales, no humanas, no personales. Y basta observar, por otra parte, la honda cultura tradicional de tantos analfabetos.

Y el desentrañamiento de este nuestro romance castellano me llevó a rebuscar en su raigambre, que se enlaza y junta y une con las de los otros romances de nuestra Iberia, con las de los otros dialectos de la común habla románica, latina. Y así me vi llevado a enquisar y requisar las diversas hablas de nuestra Iberia y su recíproca influencia. En mis clases universitarias se iniciaba el estudio del catalán y valenciano, del gallego y el portugués, y aun de otros. De mi cátedra han salido no pocos enamorados del habla y la literatura catalano-lemosina y galaico-portuguesa. De tales diferencias surge la integración.

Yo espero-y lo dije en ocasión para mí solemne y desde otra tribuna pública-que la venidera lengua secular de nuestra España máxima, de nuestra Iberia, se haga de la refundición-mejor que federación-de nuestros romances. Y que no tengamos ya en adelante que traducirnos, que es traicionamos. Tal ha sido mi labor, de que por despedida de cátedra oficial me creo en el deber de venir hoy aquí a daros cuenta. Tal ha sido mi obra. La inicié sin programa, sin definición previa. Pues tal como dijo atinadamente Goethe, con el tino de un poeta, el hacer 
preceder una definición a una obra, a un tratado de una disciplina cualquiera, es no darse cuenta de que hay que acabar la obra para poder llegar a la definición. Esto que hoy os digo no es un prólogo, sino un epílogo; no un programa, sino un epigrama, o metágrama, si se quiere. No lo que voy a hacer, sino lo que llevo ya hecho. ¡Esta es mi obra! ¿Juegos de palabras? Con ellos Quevedo, nuestro gran conceptista, nuestro gran verbalista, al adentrarse en las entrañas del romance castellano escrudiñó hurgando en el alma de su pueblo. Y lo mismo Calderón, y Gracián, y los místicos, y tantos otros. Esta fué mi obra, y obra política también. Política, es decir: civil, de civilización. Y paso por alto las discordias estrictamente políticas que en nuestra vida universitaria se produjeron. ¿Que no debe entrar la política en la Universidad? Según a qué se llame política y a qué se llame universidad. ¡De partidos, nó!; ¡de entereza, sí! ¡Triste y menguado el porvivir de España si estos templos civiles de la cultura patria se achican y oscurecen en oficinas de facultades profesionales para ganarse la vida que pasa y no queda en la historia!

En cada ciencia especial, su historia es su esencia vivificante, y lo otro, la técnica, lo codificado, no pocas veces un certificado de defunción. Hay que hacerse mártires, esto es: testigos de esa cultura; y el mártir dá su vida por la palabra, por la libertad de la palabra. Da su vida, pero no se la quita a los otros; se deja matar, pero no mata. $\mathrm{Al}$ recordar todo esto creo mostraros el hilo de propia continuidad de toda mi obra, y que este hombre, a quien se le ha supuesto tan versátil, ha seguido, en su profesión académica como en la popular, una línea seguida.

A esta mi obra responde, creo, vuestro homenaje. Lo acato. Homenaje¡siempre el filólogo!- - deriva de hominem, de hombre, y he procurado cumplir mi misión, mi destino, de hacerme hombre universitario de la España universal. Y llevar su nombre, su palabra, no sólo a las naciones a que se extendió nuestro romance, el que conquistó la mayor parte de América y porciones de las otras partidas del mundo, sino a las otras que sienten y piensan en otros idiomas. Se conquista con la palabra. Más ha ganado para España el Verbo castellano por la pluma de Cervantes en su "Quijote", hijo de palabra, que ganó Don Juan de Austria con su espada en la batalla de Lepanto. Me he esforzado por conocerme mejor para conocer mejor a mi pueblo-en el espejo, sobre todo, de su lengua-para que luego nos conozcan mejor los demás pueblos-y conocerse lleva a quererse-y, sobre todo, para ser por Dios conocidos, esto es: nombrados, y vivir en su memoria, que es la historia, pensamiento divino en nuestra tierra humana.

Y mis últimas palabras de despedida, compañeros de escuela, maestros y estudiantes, estudiosos todos: Tened fe en la palabra, que es la cosa vivida; sed hombres de palabra, hombres de Dios, Suprema Cosa y Palabra Suma, y que El nos reconozca a todos como suyos en España. ¡Y a seguir estudiando, trabajando, hablando, haciéndonos y haciendo a España, su historia, su tradición, su porvivir, su ventura! Y ¡ 